\title{
Effect of paddy straw and sugarcane bagasse on growth and survival of giant freshwater prawn Macrobrachium rosenbergii (de Man, 1879)
}

\author{
MRIDULA RAJESH, J. K. MANISSERY AND K. M. RAJESH* \\ College of Fisheries, Karnataka Veterinary, Animal and Fisheries Sciences University, Mangalore - 575002 \\ Karnataka, India \\ "Mangalore Research Centre of ICAR-Central Marine Fisheries Research Institute, Hoige Bazar \\ Mangalore - 575 001, Karnataka, India \\ e-mail: mridularajesh789@yahoo.co.in
}

\begin{abstract}
Effect of artificial substrates on growth and survival of giant freshwater prawn Macrobrachium rosenbergii (de Man, 1879) in the nursery and grow-out rearing was evaluated. Nursery rearing was conducted for a period of 35 days in nine $1 \mathrm{~m}^{3}$ cement tubs with $15 \mathrm{~cm}$ soil base. Three tubs without substrates served as control (C) while three tubs each with $200 \mathrm{~g}$ of sugarcane bagasse (SB) or $200 \mathrm{~g}$ of paddy straw (PS) formed the treatments. Each tub was stocked with 15 post-larvae (mean weight, $0.01 \mathrm{~g}$ ). Grow-out rearing was conducted for 90 days in six $25 \mathrm{~m}^{2}$ cement cisterns, of which three cisterns without substrate served as control (C) and three with $5 \mathrm{~kg}$ sugarcane bagasse (SB) served as treatment. Each cistern was stocked with 25 juveniles (mean weight, $0.55 \mathrm{~g}$ ). The average phytoplankton and zooplankton abundance in water as well as algae and food organisms attached on the substrate in the nursery phase was greater in bagasse than in paddy straw treatments. Addition of substrate resulted in higher growth and survival both in nursery and grow-out phase. Prawns grown in cisterns provided with substrates were of more uniform size than those in control cisterns. The study recommends the use of substrate based aquaculture for nursery and grow-out rearing of M. rosenbergii.
\end{abstract}

Keywords: Biofilm, Freshwater prawn, Growth, Macrobrachium rosenbergii, Organic substrates, Survival

\section{Introduction}

Microbial biofilm on substrates in aquatic system plays an important role in enhancing fish production (Ramesh et al., 1999; Umesh et al., 1999; Mridula et al., 2005; Rajesh et al., 2008; Gowda et al., 2012; Milstein et al., 2013). Importance of substrates in the culture of shrimp and freshwater prawn is very well recognised (Tidwell et al., 1999; 2000; Uddin et al., 2007). Periphyton based fish culture practice is developing as an alternative to feed based culture system due to high cost incurred for the artificial diets (Keshavanath et al., 2017). The formation of periphyton biofilm on substrates could be used for improving water quality in enriched brackishwater shrimp ponds (Khatoon et al., 2007). Addition of substrate "Aqua-mats ${ }^{\mathrm{TM}}$ allowed a substantial increase in density for juvenile prawn production and the increased density produced little or no decline in growth or survival (Peterson and Griffith, 1999). The addition of solid substrate produced a direct linear increase in total production (Tidwell et al., 2000), survival (Asaduzzaman et al., 2008) and net yield (Uddin et al., 2007) of Macrobrachium rosenbergii (de Man, 1879).
Even though, heterotrophic food can be produced from a variety of carbon sources, the carbohydrate rich raw materials of agricultural origin are more prominent. Use of agricultural wastes for heterotrophic food production serves two important purposes viz., it can be converted to protein rich microbial biomass and at the same time reduce the problem of waste disposal (Mridula, 2003).

Considering the above rationale, the present experiment was designed to evaluate the effects of two locally available organic substrates, sugarcane bagasse and paddy straw on growth and survival of giant freshwater prawn, $M$. rosenbergii in the nursery and grow-out phases.

\section{Materials and methods}

Nursery rearing

The study was carried out for a period of 35 days in 9 cement tubs of $1 \times 1 \times 1 \mathrm{~m}$ size having $15 \mathrm{~cm}$ of soil base filled with $80 \pm 2 \mathrm{~cm}$ water. Three tubs without substrates served as control (C). Sugarcane bagasse (SB) and paddy straw (PS) tied in the form of bundles of 0.60-0.75 m length were suspended at the rate of $200 \mathrm{~g} \mathrm{tub}^{-1}\left(2,000 \mathrm{~kg} \mathrm{ha}^{-1}\right)$ in the water column in triplicate tubs from horizontally placed bamboo poles. All the tubs were initially manured 
with $200 \mathrm{~g}\left(2,000 \mathrm{~kg} \mathrm{ha}^{-1}\right)$ of poultry droppings. Each tub was stocked with 15 post-larvae $\left(150,000 \mathrm{ha}^{-1}\right)$ of $M$. rosenbergii (mean weight, $0.01 \mathrm{~g}$ ) seven days after the addition of manure and substrates. Fish meal-based feed (30\% protein) prepared as per Jayaram and Shetty (1981) was fed daily at $10 \%$ of the body weight in two equal meals to the prawns in all nine tubs.

Water samples from all the tanks were analysed once in every seven days between 0800 and $0900 \mathrm{hrs}$ for different parameters. Temperature and $\mathrm{pH}$ were recorded using a Horiba (Japan) water quality analyser (Model U-10). Dissolved oxygen, free carbon dioxide, total alkalinity, total ammonia $\left(\mathrm{NH}_{4}-\mathrm{N}\right)$, nitrite $\left(\mathrm{NO}_{2}-\mathrm{N}\right)$, nitrate $\left(\mathrm{NO}_{3}-\mathrm{N}\right)$ and phosphate $\left(\mathrm{PO}_{4}-\mathrm{P}\right)$ were analysed following standard procedures (APHA, 1995). Plankton (collected by filtering 201 of water using a $60 \mathrm{~mm}$ net) and periphyton (scraped from $1 \mathrm{~cm}^{2}$ area) were sampled once a week and counted using a Sedgewick Rafter Cell (Krishna and Co., Kochi, India) (Jhingran et al., 1969; Umesh et al., 1999). For the estimation of wet and dry weight of plankton, 101 of water sample was filtered through plankton net (60 mm mesh) and the residue transferred to aluminum foils, weighed (Omori and Ikeda, 1937), dried in a hot air oven at $60^{\circ} \mathrm{C}$, cooled in a desiccator and again weighed. Total plate count (TPC) of bacteria in the water and on the substrate was estimated at weekly intervals on nutrient agar plates by the spread plate method (Anwar et al., 1992). TPC was estimated as colony forming unit (CFU) per gram of substrate.

Finally, all the surviving prawns were harvested and their lengths and weights were recorded. Further, survival and specific growth rates (SGR in \% body weight day ${ }^{-1}$ ) were calculated. Proximate composition of biofilm was analysed following AOAC (2000) procedures.

\section{Grow-out rearing}

The experiment was carried for a period of 90 days in six cement cisterns $(5 \times 5 \times 1 \mathrm{~m})$ provided with $15 \mathrm{~cm}$ of sandy-loam soil base and filled with $80 \pm 2 \mathrm{~cm}$ of water. Three cisterns without substrate served as control (C). Sugarcane bagasse (SB) tied as bundles of 0.5-0.6 m length were suspended in the water column from horizontally placed bamboo poles in three cisterns @ $5 \mathrm{~kg}$ per cistern $\left(2,000 \mathrm{~kg} \mathrm{ha}^{-1}\right)$. All the cisterns were initially manured with dry poultry manure at $5 \mathrm{~kg}$ per cistern $\left(2,000 \mathrm{~kg} \mathrm{ha}^{-1}\right)$, followed by re-fertilisation at $0.5 \mathrm{~kg}$ per cistern $\left(200 \mathrm{~kg} \mathrm{ha}^{-1}\right)$ every month. All the cisterns were stocked with 25 juveniles $\left(10,000 \mathrm{ha}^{-1}\right)$ of $M$. rosenbergii (mean weight, $0.55 \mathrm{~g}$ ) each, seven days after the addition of substrate and manure. Fishmeal-based feed (Jayaram and Shetty, 1981) with $30 \%$ protein was fed daily at a rate of $3 \%$ of the body weight in two equal meals to prawns in all the cisterns.

The procedure followed for the analysis of water quality parameters, TPC of bacteria and plankton were the same as described above. For every sampling, about $50 \%$ of the prawns were collected from each cistern and their individual length and total weight recorded at an interval of 15 days. On termination, all the surviving prawns were harvested and their length and weight were recorded. Further, survival and SGR were estimated. RNA:DNA ratio of muscle and digestive enzyme activity in the gut were also estimated. The extraction and estimation of muscle nucleic acid and the enzyme activity were carried out as described by Gangadhara et al. (1997). Proximate composition of biofilm and prawn muscle sample was analysed following AOAC (2000) procedures.

\section{Statistical analyses}

Data obtained in the nursery and grow-out experiments were subjected to statistical analyses employing ANOVA and Duncan's multiple range test at $\mathrm{p}<0.05$ (Duncan, 1955; Snedecor and Cochran, 1968).

\section{Results}

Nursery phase

All the water quality parameters recorded were within tolerable limits for aquaculture (Table 1). Mean $\mathrm{pH}$ values were slightly alkaline, ranging from 7.54 (PS) to 7.77 (SB) indicating favourable biological conditions. Mean dissolved oxygen ranged from $5.06 \mathrm{mg} \mathrm{l}^{-1}(\mathrm{C})$ to $5.15 \mathrm{mg} \mathrm{l}^{-1}$ (PS). Substrate-based treatments recorded lower ammonia and nitrite concentrations than control. However, nitrate concentration was higher in sugarcane bagasse and paddy straw added cisterns as compared to control cisterns. There was no significant difference $(\mathrm{p}<0.05)$ in the measured water-quality parameters between the treatments except for ammonia, nitrite, nitrate and phosphate.

The mean value of TPC of bacteria in water did not differ significantly among the treatments (Table 2). Sugarcane bagasse recorded significantly higher mean bacterial density $\left(2.06 \times 10^{6} \mathrm{~g}^{-1}\right)$ than paddy straw $(1.54$ $\left.\mathrm{x} 10^{6} \mathrm{~g}^{-1}\right)$.

The average phytoplankton density in water was highest in SB $\left(141 \mathrm{ml}^{-1}\right)$ followed by PS $\left(117 \mathrm{ml}^{-1}\right)$ and C $\left(87 \mathrm{ml}^{-1}\right)$. Mean number of attached algal cells on SB was higher $\left(419 \mathrm{~cm}^{-2}\right)$ than those associated with PS $\left(342 \mathrm{~cm}^{-2}\right.$ ) (Table 2). The major groups of phytoplankton in water and attached algae on the substrate in order of abundance were: green algae $>$ blue-green algae $>$ diatoms.

The mean density of zooplankton (Table 2) was higher in SB $\left(134 \mathrm{l}^{-1}\right)$ compared to $\mathrm{C}\left(126 \mathrm{l}^{-1}\right)$ and 
Table 1 . Water quality parameters (mean $\pm \mathrm{SD})$ during nursery and grow-out phase experiments

\begin{tabular}{|c|c|c|c|c|c|}
\hline \multirow{2}{*}{ Parameter } & \multicolumn{3}{|c|}{ Nursery phase } & \multicolumn{2}{|c|}{ Grow-out phase } \\
\hline & $\overline{\mathrm{C}}$ & SB & PS & $\overline{\mathrm{C}}$ & SB \\
\hline Water temperature $\left({ }^{\circ} \mathrm{C}\right)$ & $26.94 \pm 1.05^{\mathrm{a}}$ & $26.76 \pm 1.15^{\mathrm{a}}$ & $26.85 \pm 1.07^{\mathrm{a}}$ & $27.41 \pm 1.73^{\mathrm{a}}$ & $27.35 \pm 1.66^{\mathrm{a}}$ \\
\hline $\mathrm{pH}$ & $7.64 \pm 0.21^{\mathrm{a}}$ & $7.77 \pm 0.21^{\mathrm{a}}$ & $7.54 \pm 0.17^{\mathrm{a}}$ & $7.77 \pm 0.38^{\mathrm{a}}$ & $7.72 \pm 0.46^{\mathrm{a}}$ \\
\hline Dissolved oxygen $\left(\mathrm{mg} \mathrm{l}^{-1}\right)$ & $5.06 \pm 0.82^{\mathrm{a}}$ & $5.13 \pm 0.96^{\mathrm{a}}$ & $5.15 \pm 0.94^{\mathrm{a}}$ & $8.22 \pm 0.85^{\mathrm{a}}$ & $7.84 \pm 0.92^{\mathrm{a}}$ \\
\hline Carbon dioxide $\left(\mathrm{mg} \mathrm{l}^{-1}\right)$ & $3.27 \pm 3.69^{\mathrm{a}}$ & $3.60 \pm 4.26^{\mathrm{a}}$ & $3.80 \pm 3.62^{\mathrm{a}}$ & $2.55 \pm 2.88^{\mathrm{a}}$ & $2.28 \pm 3.08^{\mathrm{a}}$ \\
\hline Total alkalinity $\left(\mathrm{mg} \mathrm{l}^{-1}\right)$ & $59.67 \pm 8.79^{\mathrm{a}}$ & $61.05 \pm 9.69^{\mathrm{a}}$ & $58.06 \pm 9.70^{\mathrm{a}}$ & $68.24 \pm 9.54^{\mathrm{a}}$ & $67.52 \pm 8.96^{\mathrm{a}}$ \\
\hline Total ammonia (mg at $\left.\mathrm{l}^{-1}\right)$ & $7.16 \pm 1.73^{\mathrm{a}}$ & $5.19 \pm 0.89^{b}$ & $5.32 \pm 0.94^{\mathrm{b}}$ & $4.82 \pm 0.96^{\mathrm{b}}$ & $3.34 \pm 1.08^{\mathrm{a}}$ \\
\hline Nitrite-nitrogen (mg at $\left.{ }^{1^{-1}}\right)$ & $1.79 \pm 0.33^{\mathrm{a}}$ & $1.54 \pm 0.28^{\mathrm{b}}$ & $1.52 \pm 0.30^{\mathrm{b}}$ & $1.71 \pm 0.28^{\mathrm{a}}$ & $1.28 \pm 0.32^{\mathrm{a}}$ \\
\hline Nitrate-nitrogen $\left(\mathrm{mg}\right.$ at $\left.\mathrm{l}^{-1}\right)$ & $5.15 \pm 0.74^{\mathrm{a}}$ & $6.08 \pm 0.46^{\mathrm{b}}$ & $6.21 \pm 0.49^{b}$ & $1.68 \pm 0.52^{\mathrm{a}}$ & $2.00 \pm 0.44^{\mathrm{a}}$ \\
\hline $\begin{array}{l}\text { Phosphate-phosphorus } \\
\left(\mathrm{mg} \text { at } \mathrm{l}^{-1}\right)\end{array}$ & $1.38 \pm 0.84^{\mathrm{a}}$ & $1.33 \pm 0.68^{\mathrm{a}}$ & $1.29 \pm 0.59^{b}$ & $1.29 \pm 0.64^{\mathrm{a}}$ & $1.44 \pm 0.52^{\mathrm{a}}$ \\
\hline
\end{tabular}

*Means bearing different superscripts in the same row differ significantly $(\mathrm{p}<0.05)$ for a given experiment

PS $\left(125 \mathrm{l}^{-1}\right)$. The mean value recorded for attached food organisms on the substrate was higher in SB $\left(252 \mathrm{~cm}^{-2}\right)$ than PS $\left(229 \mathrm{~cm}^{-2}\right)$. The major groups of zooplankton in water and attached food organisms on the substrate were protozoans, rotifers, ostracods and cladocerans.

The mean final weight of prawns (Table 3) was significantly higher $(\mathrm{p}<0.05)$ in SB $(1.28 \mathrm{~g})$ than PS
$(0.99 \mathrm{~g})$ and $\mathrm{C}(0.83 \mathrm{~g})$. The survival and specific growth rate (SGR) were significantly higher in SB than PS and C.

\section{Grow-out phase}

The mean values of dissolved oxygen were higher in $\mathrm{C}\left(8.22 \mathrm{mg} \mathrm{l}^{-1}\right)$ than $\mathrm{SB}\left(7.84 \mathrm{mg} \mathrm{l}^{-1}\right)$. Mean $\mathrm{pH}$ values observed were slightly alkaline; 7.72 (SB) and 7.77 (C). Total ammonia and nitrite were higher in $\mathrm{C}$ than SB while

Table 2. Average values and range of TPC and plankton during the nursery and grow-out phase experiments

\begin{tabular}{|c|c|c|c|c|c|}
\hline \multirow{3}{*}{ Parameters } & \multicolumn{3}{|c|}{ Nursery phase } & \multicolumn{2}{|c|}{ Grow-out phase } \\
\hline & \multicolumn{5}{|c|}{ Treatment } \\
\hline & $\mathrm{C}$ & SB & PS & $\mathrm{C}$ & SB \\
\hline $\begin{array}{l}\text { TPC of bacteria in water } \\
\left(\mathrm{CFU} \times 10^{4} \mathrm{ml}^{-1}\right)\end{array}$ & $6.07^{\mathrm{a}}(0.78-13.6)$ & $6.80^{\mathrm{a}}(0.64-15.1)$ & $6.46^{\mathrm{a}}(0.64-13.92)$ & $9.73^{\mathrm{a}}(0.67-49.33)$ & $11.24^{\mathrm{b}}(0.71-53.33)$ \\
\hline $\begin{array}{l}\text { TPC of bacteria on substrate } \\
\left(\mathrm{CFU} \mathrm{U}^{\prime} 10^{6} \mathrm{~g}^{-1}\right)\end{array}$ & - & $2.06^{\mathrm{b}}(0.86-4.90)$ & $1.54^{\mathrm{a}}(0.44-3.9)$ & - & $16.18(5.87-49)$ \\
\hline $\begin{array}{l}\text { Phytoplankton in water } \\
\left(\text { no. } \mathrm{ml}^{-1} \text { ) }\right.\end{array}$ & $87^{\mathrm{a}}(10-195)$ & $141^{\mathrm{c}}(25-220)$ & $117^{\mathrm{b}}(15-225)$ & $111^{\mathrm{a}}(33-222)$ & $120^{\mathrm{a}}(25-242)$ \\
\hline $\begin{array}{l}\text { Phytoplankton on substrate } \\
\left(\text { no. } \mathrm{cm}^{-2}\right)\end{array}$ & - & $419^{\mathrm{b}}(100-600)$ & $342^{\mathrm{a}}(75-490)$ & - & $267(135-362)$ \\
\hline $\begin{array}{l}\text { Zooplankton in water } \\
\left(\text { no. } 1^{-1}\right)\end{array}$ & $125^{\mathrm{a}}(15-205)$ & $134^{\mathrm{b}}(10-210)$ & $126^{\mathrm{a}}(10-240)$ & $122^{\mathrm{a}}(28-198)$ & $142^{\mathrm{b}}(13-235)$ \\
\hline $\begin{array}{l}\text { Zooplankton } \\
\text { on substrate }\left(\text { no. } \mathrm{cm}^{-2}\right)\end{array}$ & - & $252^{\mathrm{a}}(50-410)$ & $229^{\mathrm{a}}(25-390)$ & - & $187(88-350)$ \\
\hline
\end{tabular}

${ }^{*}$ Means bearing different superscript letters in the same row differ significantly $(\mathrm{p}<0.05)$ for a given experiment

Table 3. Length-weight, survival and specific growth rate (mean $\pm \mathrm{SD})$ of $M$. rosenbergii in the nursery and grow-out phase experiments

\begin{tabular}{lllll}
\hline Treatment $^{*}$ & Average length $(\mathrm{cm})$ & Average weight $(\mathrm{g})$ & Survival $(\%)$ & SGR $(\% /$ day $)$ \\
\hline Nursery phase & & & \\
\hline C & $4.79 \pm 0.14^{\mathrm{a}}$ & $0.83 \pm 0.06^{\mathrm{a}}$ & $62.22 \pm 7.7^{\mathrm{a}}$ & $6.85 \pm 0.10^{\mathrm{a}}$ \\
SB & $5.59 \pm 0.30^{\mathrm{b}}$ & $1.28 \pm 0.11^{\mathrm{c}}$ & $86.67 \pm 13.3^{\mathrm{b}}$ & $7.52 \pm 0.12^{\mathrm{c}}$ \\
PS & $5.08 \pm 0.10^{\mathrm{c}}$ & $0.99 \pm 0.07^{\mathrm{b}}$ & $80.00 \pm 11.5^{\mathrm{b}}$ & $7.12 \pm 0.11^{\mathrm{b}}$ \\
\hline Grow-out phase & & & \\
\hline C & $10.10 \pm 0.75^{\mathrm{a}}$ & $10.43 \pm 0.91^{\mathrm{a}}$ & $65.33 \pm 1.53^{\mathrm{a}}$ & $1.42 \pm 0.84^{\mathrm{a}}$ \\
SB & $11.40 \pm 0.27^{\mathrm{b}}$ & $12.60 \pm 0.44^{\mathrm{b}}$ & $85.33 \pm 0.58^{\mathrm{b}}$ & $1.51 \pm 0.36^{\mathrm{a}}$ \\
\hline
\end{tabular}

*Means bearing different superscripts in the same column differ significantly $(\mathrm{p}<0.05)$ 
nitrate and phosphate were higher in SB than C. However, no significant differences were $(p>0.05)$ observed for all the water quality parameters, except for total ammonia (Table 1).

The introduction of manure and substrate resulted in a rapid increase in bacterial biomass (CFUs $\mathrm{ml}^{-1}$ ) both in water and on the substrate. The overall average value of TPC of bacteria in water was higher in SB (11.24 $\mathrm{x}$ $\left.10^{4} \mathrm{ml}^{-1}\right)$ than $\mathrm{C}\left(9.73 \times 10^{4} \mathrm{ml}^{-1}\right)$ and TPC on the substrate (SB) was very high $\left(16.18 \times 10^{6} \mathrm{~g}^{-1}\right)$ (Table 2). There was a rapid increase in the density of phytoplankton in water and attached algae on substrate after initial fertilisation and addition of substrates. The average phytoplankton density in water was higher in SB $\left(120 \mathrm{ml}^{-1}\right)$ than $\mathrm{C}\left(111 \mathrm{ml}^{-1}\right)$ (Table 2$)$. The phytoplankton recorded were mainly blue-green algae, green algae and diatoms. The average number of attached algae on substrate was $267 \mathrm{~cm}^{-2}$ (Table 2). The major groups of attached algae encountered on the substrate were green algae, blue-green algae and diatoms.

The average density of zooplankton in water recorded was $122 \mathrm{l}^{-1}$ in $\mathrm{C}_{\text {and }} 142 \mathrm{l}^{-1}$ in SB (Table 2). The average density of attached zooplankton on the substrate was
$187 \mathrm{~cm}^{-2}$. The major groups of zooplankton observed were protozoans, rotifers, ostracods and cladocerans.

The final mean length and weight of prawn recorded was higher $(11.4 \mathrm{~cm}$ and $12.6 \mathrm{~g})$ in $\mathrm{SB}$ than $(10.1 \mathrm{~cm}$ and $10.43 \mathrm{~g}$ ) $\mathrm{C}$ (Table 3 ). The survival rate of prawn was significantly higher in SB $(85.33 \%)$ than C $(65.3 \%)$. The

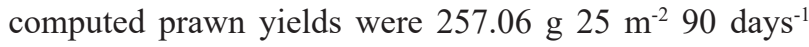
for SB and $161.36 \mathrm{~g} 25 \mathrm{~m}^{-2} 90$ days $^{-1}$ for C.

The percentage of protein recorded in the prawn muscle was higher in SB (17.36) than C (14.18) (Table 4). Fat and nitrogen free extract (NFE) levels were almost similar in both $\mathrm{C}$ and SB. Significantly higher RNA, DNA, and RNA:DNA ratio (Table 5) were recorded in $\mathrm{SB}\left(14.92,4.03\right.$ and $3.71 \mathrm{mg} \mathrm{g}^{-1}$ respectively) compared to $\mathrm{C}\left(8.75,3.33\right.$ and $2.64 \mathrm{mg} \mathrm{g}^{-1}$ respectively).

The activity of protease was higher $(\mathrm{p}<0.05)$ in prawn intestine and hepatopancreas from SB than in those from C (Table 5). However, there was no significant difference in lipase and amylase activities in the intestine and hepatopancreas of prawns harvested from the two treatments.

Table 4. Proximate composition of muscle of M. rosenbergii (expressed on wet weight basis) and biofilm grown on sugarcane bagasse (expressed on dry weight basis) in grow-out phase experiment

\begin{tabular}{lllllll}
\hline Treatments & Moisture (\%) & Crude protein (\%) & Crude fat (\%) & Ash (\%) & Crude fibre (\%) & ${ }^{*}$ NFE. $(\%)$ \\
\hline Prawn from C & 72.40 & 14.18 & 7.84 & 2.96 & - & 2.62 \\
Prawn from SB & 74.85 & 17.36 & 7.55 & 2.42 & - & 2.18 \\
Biofilm on bagasse & - & 16.36 & 1.78 & 19.28 & 25.13 & 37.45 \\
\hline
\end{tabular}

*N FE - Nitrogen free extract

Table 5. Mean RNA, DNA, RNA/DNA ratio in the muscle and specific activities of gut digestive enzymes in M. rosenbergii from grow-out phase experiment

\begin{tabular}{lll}
\hline \multirow{2}{*}{ Parameter } & \multicolumn{2}{c}{ Treatments $^{* *}$} \\
\cline { 2 - 3 } RNA $\left(\mathrm{mg} \mathrm{g}^{-1}\right)$ & $8.75^{\mathrm{a}}$ & $14.92^{\mathrm{b}}$ \\
DNA $\left(\mathrm{mg} \mathrm{g}^{-1}\right)$ & $3.33^{\mathrm{a}}$ & $4.03^{\mathrm{b}}$ \\
RNA:DNAratio & $2.64^{\mathrm{a}}$ & $3.71^{\mathrm{b}}$ \\
${ }^{*}$ Protease & & \\
$\quad$ Intestinal & $27.75^{\mathrm{a}}$ & $49.05^{\mathrm{b}}$ \\
$\quad$ Hepatopancreatic & $16.95^{\mathrm{a}}$ & $25.98^{\mathrm{b}}$ \\
${ }^{*}$ Amylase & & \\
$\quad$ Intestinal & $82.87^{\mathrm{a}}$ & $83.99^{\mathrm{a}}$ \\
$\quad$ Hepatopancreatic & $40.88^{\mathrm{a}}$ & $40.62^{\mathrm{a}}$ \\
* Lipase & & \\
Intestinal & $0.55^{\mathrm{a}}$ & $0.57^{\mathrm{a}}$ \\
$\quad$ Hepatopancreatic & $0.83^{\mathrm{a}}$ & $0.88^{\mathrm{a}}$ \\
\hline
\end{tabular}

* $\mu$ moles of product liberated $\mathrm{h}^{-1} \mathrm{mg}$ tissue protein ${ }^{-1}$

**Means bearing different superscript in the same row differ significantly $(\mathrm{p}<0.05)$

\section{Discussion}

The lowest values of dissolved oxygen recorded in both nursery and grow-out rearing during the first week of the experiment in all the treatments are characteristic of water with predominant heterotrophic food production (Moriarty, 1997). Ammonia, nitrite, nitrate, phosphate and alkalinity values recorded in the present study were generally within the suitable limits for fish culture (Azim, 2001; Mridula et al., 2005). Substrate-based treatments recorded lower ammonia and nitrite and higher nitrate concentrations than the control. Development of biofilm on substrates in aquaculture systems can act as in situ biofilter for reduction of harmful ammonia load (Joice et al., 2002; Rajesh et al., 2008; Bharti et al., 2016). Langis et al. (1988) recorded lower ammonia in aquaria harbouring bacterial biofilm on glass panels.

Addition of substrate had a substantial effect on prawn growth. Increasing availability of surface area through the 
addition of artificial substrate, produced a direct linear increase in total production of $M$. rosenbergii (Tidwell et al., 2000). The higher growth recorded in substrate based treatments in both nursery and grow-out experiment could be due to the higher production of phytoplankton, zooplankton and microbial biofilm. Further, prawns grown in tubs and cement cisterns provided with substrates were significantly larger and had a more uniform size than those from cisterns without substrate.

The increased surface area due to substrate provides increased benthic habitat for the growing algal and bacterial colonies upon which prawns could graze and find protection during molting. Thompson et al. (2000) confirmed that the shrimp directly consume biofilm after the examination of its gut contents. Several reports are already there on significant increase in total production of marine and freshwater prawns in substrate-based systems (Ra Anon et al., 1984; Daryl, 2001; Uddin et al., 2007; Khatoon et al., 2007; Asaduzzaman et al., 2008). The addition of substrates to ponds allowed for an increase in prawn production by $14 \%$ and mean size by $13 \%$. Tidwell et al. (1998) evaluated the effect of added substrates on prawns stocked at relatively lower density $\left(59,280 \mathrm{ha}^{-1}\right)$, and found that the production and mean size increased by 20 and $23 \%$ respectively. Increase in survival from 62.8 to $72 \%$ and increase in the net yield by $23 \%$ was recorded in ponds added with substrates (Asaduzzaman et al., 2008). The higher percentage survival recorded in the substrate based treatment could be attributed to the provision of additional shelter by substrates and the positive effect of biofilm on water quality in terms of ammonia.

The nucleic acid content was higher in prawns harvested from substrate-based cisterns compared to those from control cisterns. This could be due to the provision of extra protein from biofilm which reflected on the muscle protein of prawn harvested from the substrate added treatments. High protein content in the gut of the shrimps fed on biofilm was recorded by Tidwell et al. (2000). It has been reported that RNA : DNA ratios in body tissues can be used to monitor protein synthesis and growth in fish (Bulow, 1970; Wright and Martin, 1985; Khan and Zafri, 1991). In the present study, higher RNA was recorded in prawns harvested from the substrate based treatments indicating higher protein synthesis and also higher growth. Protease activity was the highest in prawn from substrate-based treatment than control. In general, protease activity in the intestinal segments is higher than that in hepatopancreas. Bazaz and Keshavanath (1993), Manjappa (1999) and Mridula et al. (2003, 2005) reported similar observations in Tor khudree, Catla catla, Labeo fimbriatus and Labeo rohita respectively. Dietary protein content is known to effect protease activity
(Mukhopadhyay et al., 1978; Phadate, 1987; Gangadhar et al., 1997; Mridula et al., 2003, 2005).

Results of the present study clearly demonstrated that the addition of paddy straw and sugarcane bagasse resulted in improvement of water quality by lowering ammonia and led to good and uniform growth, survival and higher muscle protein content in $M$. rosenbergii. Hence substrate-based aquaculture can be effectively adopted for the nursery and grow-out rearing of $M$. rosenbergii. Use of easily available and biodegradable agricultural plant residues as substrate helps in proper bio-conversion.

\section{Acknowledgments}

The financial support received from the Indian Council of Agricultural Research (ICAR), New Delhi, India is gratefully acknowledged.

\section{References}

Anwar, H., Strap, J. L. and Costerton, J. W. 1992. Susceptibility of biofilm cells of Pseudomonas aeruginosa to bactericidal actions of whole blood serum. FEMS Microbiol. Lett., 92: 235-241.

AOAC 2000. Official methods of analysis, $17^{\text {th }}$ edn. Association of Official Analytical Chemists, Gaithersburg, MD, USA, $2200 \mathrm{pp}$.

APHA 1995. Standard methods for the examination of water and waste water, $19^{\text {th }}$ edn. American Public Health Association, Washington, DC, USA. 1108 pp.

Asaduzzaman, M., Wahab, M. A., Verdegem, M. C. J., Huque, S. M., Salam, A. and Azim, M. E. 2008. C/N ratio control and substrate addition for periphyton development jointly enhance freshwater prawn Macrobrachium rosenbergii production in ponds. Aquaculture, 280: 117-123.

Azim, M. E. 2001. The potential of periphyton-based aquaculture production systems. Ph. D thesis. Wageningen University, Netherlands. http://edepot.wur.nl/199010

Bazaz, M. M. and Keshavanath, P. 1993. Effect of feeding different levels of sardine oil on growth, muscle composition and digestive enzyme activities of mahseer, Tor khudree. Aquaculture, 115: 111-119.

Bharti, V., Pandey, P. K., Vennila, A., Rajkumar, M. and Ajima, M. N. O. 2016. Water quality, survival and growth performance of Cirrhinus mrigala (Hamilton 1822) in substrate based tanks. Asian Fish. Sci., 29: 137-150.

Bulow, F. J. 1970. RNA-DNA ratios as indicators of recent growth rates of fish. J. Fish. Res. Board Can., 27: 2343-2349.

Daryl, E. J. 2001. Intensive nursery uses strategy for improved shrimp health. Aquac. Mag., 26: 67-72.

Duncan, D. B. 1955. Multiple range and multiple F-tests. Biometrics, 11: 1-42. 
Gangadhara, B., Nandeesha, M. C., Varghese, T. J. and Keshavanath, P. 1997. Effect of varying protein and lipid levels on the growth of rohu, Labeo rohita. Asian Fish. Sci., 10: 139-147.

Gowda, G., Gyanendra Singh, Rajesh, K. M., Mridula, R. M. and Shankar, K. M. 2012. Development of biofilm on artificial substrates in a brackishwater pond near Mangalore, south-west coast of India. J. Aquac. Trop., 27: 13-23.

Jayaram, M. G. and Shetty, H. P. C. 1981. Formulation, processing and water stability of two new pelleted fish feeds. Aquaculture, 23: 355-359.

Jhingran, V. G., Natarajan, A. V., Banerjea, S. M. and David, A. 1969. Methodology on reservoir fisheries investigations in India. Bulletin of the Central Inland Fisheries Research Institute, Barrackpore, India, No. 12: 109 pp.

Joice, A., Shankar, K. M. and Mohan, C. V. 2002. Effect of bacterial biofilm in nursery on growth, survival and resistance to Aeromonas hydrophila of common carp, Cyprinus carpio. J. Aquac. Trop., 17: 283-298.

Keshavanath, P., Leao da Fonseca, F. A., Affonso, E. G., Nobre, A. D. and Jeffson, N. P. 2017. Periphyton growth on three bio-substrates and its influence on the performance of Jaraqui (Semaprochilodus insignis). Int. J. Aquac., 7(14): 86-93.

Khan, M. A. and Zafri, A. K. 1991. Protein and nucleic acid concentration in the muscle of the catfish, Clarias batrachus fed at different protein levels. Asian Fish. Sci., 4: $75-84$.

Khatoon, H., Yusoff, F., Banerjee, S., Shariff, M. and Bujang, J. S. 2007. Formation of periphyton biofilm and subsequent biofouling on different substrates in nutrient enriched brackishwater shrimp ponds. Aquaculture, 273: 470-477.

Langis, R., Proulx, D., De La Noue, J. and Coulture, P. 1988. Effects of bacterial biofilm on intensive Daphnia culture. Aquac. Eng., 7: 21-38.

Manjappa, K. 1999. Influence of diet quality and fertilisation on the growth of cultivable carps. Ph. D thesis, University of Agricultural Sciences, Bangalore, India, 183 pp.

Milstein, A., Naor, A., Barki, A. and Harpaz, S. 2013. Utilisation of periphytic natural food as partial replacement of commercial food in organic tilapia culture - an overview. Transylvanian Review of Systematical and Ecological Research, 15: 49-60.

Moriarty, D. J. W. 1997. The role of microorganisms in aquaculture ponds. Aquaculture, 151: 333-349.

Mridula, R. M. 2003. Studies on biofilm production, nutritive value and its utilisation by different cultivable species of fishes and prawn. $\mathrm{Ph}$. D thesis, Mangalore University, Karnataka, India.

Mridula, R. M., Manissery, J. K., Keshavanath, P., Shankar, K. M., Nandeesha, M. C. and Rajesh, K. M. 2003. Water quality, biofilm production and growth of fringe-lipped carp (Labeo fimbriatus) in tanks provided with two solid substrates. Bioresource Tech., 87: 263-267.

Mridula, R. M., Manissery, J. K., Keshavanath, P., Shankar, K. M., Nandeesha, M. C. and Rajesh, K. M. 2005. Effects of paddy straw and sugarcane bagasse on water quality, bacterial biofilm production, growth and survival of rohu, Labeo rohita (Hamilton). Aquac. Res., 36: 635-642.

Mukhopadhyay, P. K., Dehadrai, P. V. and Banerji, S. K. 1978. Studies on intestinal protease: isolation, purification and effect of dietary proteins on alkaline protease activity of the air breathing fish Clarias batrachus (Linn.) fed isonitrogenous diets with variable energy level. Sci. Cult., 52: $230-233$.

Omori, M. and Ikeda, T. 1937. Methods in marine zooplankton ecology. John Willey and Sons, A Willey Interscience Publications, New York, USA, 332 pp.

Peterson, J. J. and Griffith, D. R. W. 1999. Intensive nursery system. Global Aquac. Advoc., 2: 60-61.

Phadate, S. V. 1987. Investigations on the digestive enzymes of some cultivable freshwater fishes. Masters Thesis, University of Agricultural Sciences, Bangalore, India, $59 \mathrm{pp}$.

Ra' Anon, Z., Cohen, D., Rappaport, U. and Zohar, G. Y. 1984. The production of freshwater prawn Macrobrachium rosenbergii in Israel. The effect of added substrate on yields in a monoculture situation. Bamidgeh, 36: 35-40.

Rajesh, K. M., Shankar, K. M., Mohan, C. V. and Mridula, R. M. 2008. Growth and resistance to Aeromonas hydrophila of Indian major carp, rohu (Labeo rohita) in cisterns treated with sugarcane bagasse as artificial substrate. In: Bondad-Reantaso, M. G., Mohan, C. V., Crumlish, M. and Subasinghe, R. P. (Eds.), Diseases in Asian Aquaculture VI Fish Health Section, Asian fisheries society, Manila, Philippines. p. 245-258.

Ramesh, M. R., Shankar, K. M. Mohan, C. V. and Varghese, T. J. 1999. Comparison of three plant substrates for enhancing carp growth through bacterial biofilm. Aquac. Eng., 19: 119-131.

Snedecor, G. W. and Cochran, G. W. 1968. Statistical methods. Oxford and IBH Publishing Company, Calcutta, India, $593 \mathrm{pp}$.

Thompson, F. L., Abreu, P. C. and Wasielesky, W. 2000. Influence of biofilm on the survival and growth of juveniles of Farafantepenaeus paulensis. In: Flos, R. and Creswell, L. (Eds.), Responsible aquaculture in the new millennium. Abstracts of contributions presented at the International Conference - AQUA 2000. European Aquaculture Society, Oostende, Belgium, p. 704-705.

Tidwell, J. H., Coyle, S. D. and Schumeister, G. 1998. Effect of added substrate on the production and population 
characteristics of freshwater prawn, Macrobrachium rosenbergii in ponds. J. World Aquac. Soc., 29: 17-22.

Tidwell, J. H., Coyle, S. D., Weibel, C. and Evans, J. 1999. Effects and interactions of stocking density and added substrate on production and population structure of freshwater prawn, Macrobrachium rosenbergii. J. World Aquac. Soc., 30: 174-179.

Tidwell, J. H., Coyle, S. D., Arnom, A. V. and Charles, W. 2000. Production response of freshwater prawn, Macrobrachium rosenbergii to increasing amounts of artificial substrate in ponds. J. World Aquac. Soc., 31: 452-458.
Uddin, M. S., Shamsul, R. S. M., Azim, M. E., Wahab, M. A., Verdegem, M. C. J. and Verreth, J. A. J. 2007. Effects of stocking density on production and economics of Nile tilapia (Oreochromis niloticus) and freshwater prawn (Macrobrachium rosenbergii) polyculture in periphytonbased systems. Aquac. Res., 38: 1759-1769.

Umesh, N. R., Shankar, K. M. and Mohan, C. V. 1999. Enhancing fish growth through plant substrate: the role of bacterial biofilm. Aquac. Int., 7: 1-10.

Wright, D. A. and Martin, F. D. 1985. The effects of starvation on RNA: DNA ratios and growth of larval striped bass, Morone saxatilis. J. Fish. Biol., 27: 479-485. 